\title{
Analysis of International Financial Cooperation Strategy under the Background of the "Belt and Road"
}

\author{
Pei Wang, Beizhong Hu, Ming Luo
}

Guizhou University of Finance and Economics, Guiyang, Guizhou, 550025

Keywords: financial cooperation strategy, The Belt and Road, international business

\begin{abstract}
The Belt and Road is an important strategic goal in China's future development plan and a new international regional economic cooperation platform. Under the far-reaching influence of the world financial crisis, the global economic recovery is weak. The Belt and Road initiative is promoting regional economic stability and prosperity. The significance of the global economic development is significant. The Belt and Road breaks through the traditional regional economic cooperation concept with the theme of trade and investment facilitation. Under the new global economic structure, the Belt and Road provides the international public products that benefit the countries and regions along the same line, and the downturn in the global economy. Growth provides new impetus and provides new solutions to the maintenance of the multilateral trading system. Policy communication, facility connectivity, trade smoothness, capital finance, and people's heart are the five main lines of the Belt and Road, including the financial support for the construction of the Belt and Road. From this, financial services for the Belt and Road Construction and development are of great significance. The paper focuses on the issue of international financial cooperation strategy in the context of the Belt and Road.
\end{abstract}

\section{Introduction}

The essence of the Belt and Road is a multi-faceted international cooperation platform. It not only spans many regions, but also has a wide range of cooperation, including infrastructure construction, energy development, business cooperation, logistics and transportation, capital investment, etc. The cooperation content emphasizes the currency circulation and financial cooperation between regions and countries. In the process of financing, it needs innovative financial products and financial services to promote the systematic development of regional finance, thereby improving the development of the Belt and Road finance. Resource allocation efficiency and improve the level of cross-regional financial development cooperation. It can be seen that there is a total and partial relationship between finance and the Belt and Road. The Belt and Road initiative needs to create a mutually beneficial economic community through finance to achieve seamless integration between regions and countries.

There are many countries and regions along the Belt and Road, the infrastructure construction is imperfect, and there is a serious shortage of funds. As the blood and economic soul of the market, financial resources are an important factor in promoting the construction of the Belt and Road, so strengthen the Belt and Road. Regional and national financial cooperation can further improve the level of financial intercommunication and expand the scope of financial cooperation. It can not only provide support for the construction of infrastructure along the route, but also enhance the overall international competitiveness of China's financial industry. In this context, Chinese financial institutions and private capital must have a developmental strategic vision of "going global", actively participate in international financial competition and cooperation, innovate financial products, broaden financing channels, optimize financial resource allocation, and improve their comprehensive competition. force.

Finance can not only meet the needs of diversified funds, but also play the leading role of "taking the line" and "taking the line" through the optimization of financial support. The Belt and Road is a large and complex system. Different countries and regions have different development characteristics. Developed countries have rich financial resources and a sound financial system. 
Therefore, they can learn from their experience in the development of the financial system to drive other countries. And regional financial development. In the early stage of the construction of the Belt and Road, large-scale infrastructure construction was focused on economic and trade cooperation. The development of the Belt and Road was mainly based on the development and utilization of resources and energy, whether it was the infrastructure construction in the early stage or the later stage. With comprehensive economic and trade cooperation, the Belt and Road will play a leading role in driving investment opportunities in more industrial chains. It should be emphasized that the countries and regions along the Belt and Road are mostly developing countries and emerging economies. Compared with the current capital needs, the sustainable economic growth model is more important, and China has undergone 40 years of reform and development. It is of great significance to form a new model of economic development that spreads and spreads this model in countries and regions along the Belt and Road.

\section{Difficulties in International Financial Cooperation in the Context of the Belt and Road}

In the context of economic globalization, international financial cooperation is an inevitable choice for the development of the Belt and Road, and an important means for all economies to cope with the crisis. However, there are still many practical difficulties in international financial cooperation in the Belt and Road. Specifically in the following aspects:

The countries and regions along the Belt and Road are not only rich in natural resources, but also have strategic location advantages. Therefore, the development prospects are very broad. Not only China, the United States, Russia and other world powers and powers also express their strategic interests in the region. For example, the United States led the signing of the Pacific Partnership Agreement (TPP) as an important part of the "return to Asia-Pacific" strategy; while Russia, Kazakhstan, and Belarus signed the Eurasian Economic Union Treaty in 2014, and In 2015, the Eurasian Economic Union was launched. In the development process of the Belt and Road, it is an important issue to find the convergence between the five main lines of policy communication, trade smoothness, road connectivity, popular communication, and currency circulation in the complex world game relationship.

The Belt and Road covers a wide range of areas, from the Asia-Pacific economic circle to the European economic circle, which runs through the entire Eurasia continent. The economic development and financial development of different countries and regions vary widely, while different countries target supply. The interests of chain cooperation are also different. For example, countries with low levels of economic development tend to focus on infrastructure construction, while emerging economies focus more on foreign trade protection. Economically developed countries will focus on the integration of different cooperation mechanisms and investment policies. Therefore, the standards of customs clearance, quarantine, transportation and other aspects of the countries and regions along the Belt and Road are not uniform, and will become an important constraint for the smooth development of the Asia-Pacific supply chain partnership.

At present, most of the financial cooperation between China and most countries along the Belt and Road is still in the form. Substantial regional financial cooperation is still in its infancy. For example, although China has signed many regional financial cooperation agreements with many Central Asian countries, However, the number of cooperative entities established is relatively small; regional financial cooperation is still dominated by bilateral cooperation, and the proportion of multilateral financial cooperation is small; regional financial cooperation is mainly completed through policy banks, and the cooperation between commercial banks and financial institutions lacks innovation. In addition, the financial cooperation mechanisms of various countries and regions along the Belt and Road currently reflect multiple levels and intertwined features. For example, the Russian CIS Free Trade Area, the Eurasian Economic Union, Central Asia, the Gulf Cooperation Council, the Arab Cooperation Council, the South Asian Association for Regional Cooperation, the Shanghai Cooperation Organization and other regional economic cooperation organizations have greater influence in the Belt and Road. However, these regional economic cooperation organizations are dominated by different countries, and the relations between the regional economic cooperation 
organizations are complex and difficult to coordinate.

\section{The International Financial Cooperation Strategy in the Context of the Belt and Road}

Under the Belt and Road strategy, the construction and improvement of financial policy communication and coordination mechanisms in various countries will be based on multi-win and win-win, and will increase the participation of countries and regions along the line in financial cooperation and improve the level of international financial cooperation among countries along the route. At present, the existing communication platforms include the APEC Summit and the organization of the East Asia and Pacific Central Bank Governors Meeting. In addition, we must establish and improve the financial cooperation business cooperation mechanism and the finance minister dialogue mechanism to deepen the pragmatic cooperation of financial institutions in various countries along the line. . In view of the problems of financial supervision, financial policy coordination, and information disclosure among member states, it is possible to reach a deeper consensus among countries through equal consultations to promote the development of financial cooperation. Improve the concentration of cross-border funds and financial institutions, seize the good opportunities of multilateral emerging financial institutions, and promote the in-depth cooperation between China's financial institutions and overseas financial institutions, set up branches, and carry out cross-regional financing agents, syndicated loans, equity cooperation, etc. Business improves the comprehensiveness of financial services, expand the scope of financial services, and improve the degree of financial integration of countries along the line.

In the overall strategic planning of the Belt and Road, the requirements for financial support should follow the principle of "planning first, financial leading", planning and integrating various financial resources, and coordinating the promotion of Chinese enterprises, technologies, equipment, industry standards, etc. with other countries. Integrate with each other to expand the layout of the Belt and Road financial services, and better serve the construction and development of countries along the line and the real economy. The implementation of the Belt and Road strategy can be divided into three phases. In the initial phase, infrastructure construction should be carried out. At this time, financial services are mainly development finance, and the role of international development financial institutions should be fully utilized, such as Silk Road. Funds, BRICS Development Bank, AIIB, etc., such financial machine color as the main body of the Belt and Road financial support can further promote the reform of the International Monetary Fund and the World Bank. Development financial institutions are extremely inclusive. It is believed that with the continuous advancement of the Belt and Road strategy, development financial institutions can not only provide important financial support for countries along the Belt and Road, but also improve the application of Asian financial resources. After the completion of the infrastructure construction, the second phase will be carried out. The policy financial institutions in China and the countries along the Belt and Road will play their full role, and the focus of financial service support will be on the interconnection and logistics between countries. In the last stage, we can see that the economic development of countries and regions along the Belt and Road has achieved certain results. At this time, commercial financial institutions dominated, and they entered the market-oriented operation, carrying out the upstream and downstream international settlement business and risk management of the project.

The main gains of RMB internationalization mainly come from exchange rate risk cancellation, tax rate reduction, summary cost, coinage, etc. Of course, there are certain risks, including financial market risk caused by exchange rate fluctuations and increased regulation costs. To achieve a stable, orderly, and rapid internationalization of the renminbi, we must meet many realistic conditions, such as strengthening China's international status through strong diplomacy, building a sound financial system, deepening financial system reform, and improving financial-related laws and regulations. We must also change the economic growth model to reduce the trade surplus, optimize the industrial structure, and improve the domestic economic strength, so as to improve the maturity of the domestic financial market and better meet the diversified financial needs of different investment entities. In addition, in the process of RMB internationalization and the promotion of 
"the Belt and Road", a very important arrangement is to open up the domestic bond market. At present, the policy level has gradually liberalized the restrictions on foreign investors entering the market, and some foreign institutions have gradually entered the market. Therefore, it is necessary to speed up the opening of the Chinese bond market: effectively shorten the approval cycle and speed up the approval of more qualified institutional investors to enter the inter-bank bond market; on the basis of the current foreign investors entering the inter-bank bond market, they can conduct bond issuance subscriptions and spot bond transactions. As soon as possible, let go of the restrictions on its repurchase business.

\section{Conclusion}

In short, the strategic deployment of "the Belt and Road" not only conforms to the vision of our country, but also reflects the long-term interests of many countries in their economic strategy development. As the core mechanism of capital allocation, finance plays an important role in supporting and driving the construction of "the Belt and Road". The function of resource allocation in finance is also a prerequisite and guarantee for promoting win-win development among countries along the route. Our country is constantly accelerating the pace of opening up, seize this opportunity to assume the responsibilities of our country as the world's largest developing country, and provide new opportunities and space for the stability and prosperity of the world economy.

\section{References}

[1] Gao Yanfang. Research on Financial Cooperation between China and Burma Border Area under the Background of "The Belt and Road"___Taking the National Key Development and Open Experimental Area of Ruili as an Example[J].Commercial Economic Research,2017,(12):258-259

[2] Wang Nan. Discussion on Financial Cooperation under the Background of "The Belt and Road" [J]. Modern Marketing (Late), 2017, (11): 133-134

[3] Weng Dongling. Discussion on Financial Support and Cooperation Risk of "The Belt and Road" Construction [J]. Northeast Asia Forum, 2016, (10): 73-74

[4] Huang Mengfang, Lu Shanbing, Yu Shuxiu. The development of the economic integration of the Commonwealth of Independent States marked by the Eurasian Economic Union and its enlightenment to the construction of the Belt and Road [J]. Humanities Magazine, 2015(1): 70 